\title{
The Influence of Customer Relationship Management (CRM) on Customer Trust and Loyalty in PT Amartha Sejahtera
}

\author{
Finny Redjeki
}

Universitas Sangga Buana Bandung, Indonesia

finnyredjeki@usbypkp.ac.id

\begin{abstract}
This analysis aims to examine the impact of Customer Relationship Management (CRM) on PT Amartha Sejahtera customers' trust and loyalty both simultaneously and partially. PT Amartha Sejahtera is a company that provides and manages clean water for the area around Bandung Regency, especially in Cileunyi District, East Bandung. The research used was an associative survey method approach. Determination of data samples using an incidental sampling method. The unit of analysis is a customer who has been a regular customer for at least 3 months. The number of samples taken was as many as 150 people. Meanwhile, the analysis tool used is multiple regression. From the analysis, it can be concluded that simultaneous customer relationship management has a 49.6 percent positive and substantial impact on customer satisfaction. Meanwhile, partially the sub-variables of customer relationship management, namely financial bonds, and social bonds, see a 57.7 percent and 24.2 percent positive and substantial impact on consumer satisfaction. In contrast, customization bonds have a positive but negligible effect.
\end{abstract}

\section{Keywords: Customer Relationship Management, Customer Loyalty, Financial Bond, Social Bond}

\section{INTRODUCTION}

Today's economic economy is somewhat different from the economy of two decades ago. The rapid distribution of knowledge contributes to the extreme rivalry among businesses in doing business. Customers can now conveniently locate the details they need for a commodity (Kahaner, 1997). Furthermore, because of the vast number of clients, the corporation can evaluate the proper segmentation and target market to have a solid commercial focus (Kotler \& Keller 2006). In today's dynamic business, focusing on consumers is critical to achieving a sustainable competitive edge. To gain a competitive advantage with a customer focus, Business organizations need input about who their clients are, what they expect, how their customers' needs are met, and other similar considerations (Hoffman, 2000).

According to Kasali (2000), it no longer relies on revenue volume alone in obtaining profit. Still, it must be oriented towards long-term satisfaction. The company must develop company policies that include marketing, sales, service, and technology, all of which are integrated into one harmonious work unit to realize value-customer (customer value). As part of product creation, customer desires must be precisely defined. This strategy aims to surpass, rather than meet, consumer needs. As a result, the organization can better consider its customers' actions at its goals and implement effective plans and services to focus on current opportunities, build partnerships with each client, and outperform its rivals (Rygielski et al., 2002).

Meanwhile, customer loyalty can be used as a basis. Or a benchmark in taking policies to add or reduce product value for customers (Parasuraman, 2000). The company will get information from consumers, namely about interpreting, processing, and storing information about products and brands. Therefore, customer loyalty can affect consumer confidence in making purchasing decisions. Customer loyalty can show how much support a customer has for the company's product or service (Bowen \& Chen, 2001). On the other hand, customer loyalty can prove customer trust in the products or services offered by the company (Ryals, 2005).

Of course, each corporation has its plan for retaining loyal customers. To thrive and grow, businesses must implement consumer-related tactics, such as customer relationship management, in addition to introducing new products, paying greater attention to competitors' products, and selling more products than competitors (Rizal, 2003). Customer Relationship Management (CRM) is a strategy on how to optimize profitability through developing customer satisfaction. CRM is a strategy that focuses 
on all things related to customer focus (Chen \& Popovich, 2003). Yuang \& Chang (2001) suggest that customer knowledge is the key to CRM success. Without knowledge of the customer that is disseminated throughout the company, the company can fail to meet customer desires. Efforts to understand customers and strengthen customer relationships are essential in today's demand-driven economy (Bhaskara et al., 2014).

O'Brien \& Dyche (2002) states that customer relationship management is a fundamental concept to win the competition. This concept is part of marketing that regulates and builds good relationships with consumers or other related parties. Besides, customer relationship management concludes that CRM brings qualitative benefits that enhance its image through good relationships with internal and external parties. Gummesson also concluded that CRM has an approach to three essential components in customer service: lifetime value analysis, one-to-one marketing, and enterprise relationship marketing. Lifetime customer value will maximize total customer equity by managing customers as assets. While one-to-one marketing, namely the process made easier by the internet, replacing traditional mass marketing, streamlines costs.

Consumer loyalty is a strong and lasting customer pledge to re-subscribe to or regularly repurchase chosen goods or services in the future, even though the scenario and marketing campaigns can alter behavior (Griffin, 1995). Griffin stated that "Loyalty is defined as non random purchase expressed over time by some decision making unit." Wirtz \& Lovelock (2006) says that loyalty is a customer's ability to continue contributing to a brand in the long run by purchasing and using goods and services repeatedly and, better still, exclusively, and willingly endorsing the company's products to his friends and associates.
PT. Amartha Sejahtera, as a form of concern for customers, has formed a section that takes care of the company's relationship with customers. The company does not want to be late in carrying out all customer-related programs. This is done to maintain customer loyalty and trust in continuing to use the company's services. Customer loyalty is also very beneficial for the company in reducing marketing activities and costs to get customers. With the assurance of loyal customers, the company already has regular customers without working hard to convince consumers.

\section{METHOD}

The research sample is consumers who have been subscribed for at least 3 months. The sampling technique used was nonprobability sampling, where the sampling used was random sampling. The sample sufficiency is determined based on the iteration technique, and with $\alpha$ of $5 \%$ and $\beta$ of $5 \%$, the sample sufficiency is 116 people. Data were collected using a questionnaire that has been tested for validity and reliability. Each measures the variables of Financial Bonds and Social Bonds by 3 indicators; 2 indicators calculate customization Bonds. 4 indicators measure the customer loyalty variable. Data analysis was performed using multiple regression. To make it easier, calculation operations are carried out with the help of SPSS 16 Software (Sugiyono, 2006).

\section{RESULT AND DISCUSSION}

To find out how much influence financial bonds, social bonds, and customization bonds simultaneously on customer loyalty, the decision's coefficient demonstrates this (R2). The coefficient of determination (R2) derived from the test results is 0.496 , as seen in the table below:

Table 1. The coefficient of determination

\begin{tabular}{|c|c|c|c|c|c|}
\hline Model & $\mathrm{R}$ & $\mathrm{R}$ Square & $\begin{array}{c}\text { Adjusted } \\
\text { R Square }\end{array}$ & $\begin{array}{c}\text { Std Error of } \\
\text { The estimate }\end{array}$ & Durbin-Watson \\
\hline 1 & $.705^{\mathrm{a}}$ & .496 & .486 & 1.7013 & 1.398 \\
\hline
\end{tabular}

a. Predictor: (Constant), X3, X2, X1

b. Dependent Variable: $Y$

This means that together with the variables of Financial Bonds (X1), Social Bonds (X2), and Customization Bonds (X3), only have an effect of $49.6 \%$ on customer loyalty. The $49.6 \%$ figure here means that each additional 49.6 units of Financial Bonds, Social Bonds, and Customization Bonds will result in a different 49.6 units of customer loyalty. The remaining $50.4 \%$ was caused by other variables outside the three variables that were not involved in this study.

The simultaneous significance test can be seen in the following table: 
Table 2. Testing the Significance of Simultaneous Effects

\begin{tabular}{|l|r|r|r|l|l|}
\hline Model & Sum Of Square & \multicolumn{1}{|c|}{ Df } & Mean Square & F & Sig \\
\hline Regression & 417.977 & 3 & 139.325 & 48.132 & $.000^{\mathrm{a}}$ \\
\hline Residual & 422.628 & 146 & 2.896 & & \\
\hline Total & 840.605 & 149 & & & \\
\hline
\end{tabular}

a. Predictor: (Constant), X3, X2, X1

b. Dependent Variable: $\mathrm{Y}$

According to table 2, CRM has a significant impact on consumer satisfaction at the same time. This is shown by the estimated $F$ value of 48,132 , which is higher than the F table.
Furthermore, the partial effect analysis was carried out. To see the effect partially, It is seen in table 3 below:

Table 3. Partial Effects

Coefficients $^{\text {a }}$

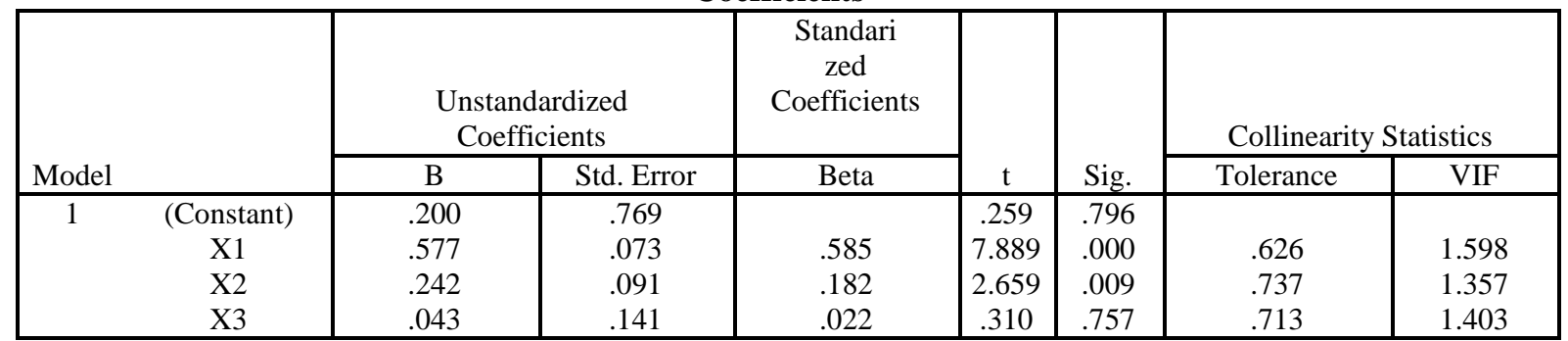

a. Dependent Variable: Y

The vector Financial Bonds (X1) have a regression coefficient value I of 0.577 , Social Bonds (X2) have a regression coefficient value of I of 0.242 , and Customization Bonds (X3) have a regression coefficient value I of 0.043 , as seen in the table above.
To test the significance of this effect, the ttest is then performed. The t-test results are shown in Table 4 below:

Table 4. Significance Test of Partial Effects

\begin{tabular}{|c|c|c|c|}
\hline Variable & $\mathbf{t}_{\text {count }}$ & $\mathbf{t}_{\text {table }}$ & Conclusion \\
\hline $\mathrm{X}_{1}$ & 7.889 & 1.960 & Significant \\
\hline $\mathrm{X}_{2}$ & 2.659 & 1.960 & Significant \\
\hline $\mathrm{X}_{3}$ & 0.310 & 1.960 & Not Significant \\
\hline
\end{tabular}

The $t$ value for the Financial Bonds variable is 7.889 , according to the table above. This value is higher than the t table value of 1.960 . Since $t$ count $>$ $\mathrm{t}$ table, it is possible to infer that the Financial Bonds variable and consumer satisfaction have a substantial relationship. This is also confirmed by the Financial Bonds variable's significance value of 0.000 , which is less than the necessary significance amount of 0.05 .

Customer satisfaction is positively and significantly affected by the vector Financial Bonds (X1). This suggests that the more the Financial Bonds variable is implemented, the greater the consumer loyalty; in addition to the meaning derived from the measurements taken, it can explain the population's response or generalize it. This finding supports Zethaml and Bitner's hypothesis that the introduction of customer relationship management linked to financial bonds impacts customer loyalty.
The Social Bonds vector has a $\mathrm{t}$ value of 2.659. This value reaches the table value of 1.960 . Since $t$ count $>t$ table, it is possible to infer that the Social Bonds component and consumer satisfaction have a substantial relationship. This is also supported by the Social Bonds variable's significance value of 0.009 , which is less than the necessary significance amount of 0.05 .

Customer satisfaction is positively and dramatically influenced by the Social Ties vector (X2). This implies that in addition to the meaning derived from the samples collected, the greater the execution of the Social Bonds component, the higher the consumer loyalty; in other terms, it can characterize the population's response or, in other words, it can be generalized. These results are in line with the theory presented by Zethaml and Bitner that the implementation of customer relationship 
management related to social bonds influences customer loyalty.

The $\mathrm{t}$-count value for the Customization Bonds variable is 0.310 . This value reaches the t table value of 1.960 . Since $t$ count $>t$ table, it is possible to infer that the relationship between the Customization Bonds vector and consumer satisfaction is negligible. This is also confirmed by the Customization Bonds variable's significance value of 0.757 , which is greater than the minimum significance amount of 0.05 .

This variable has a minimal effect on customer loyalty. This influence is only limited to the existing sample; it cannot be generalized; in other words, it does not affect. These results follow the theory presented by Zethaml and Bitner that the implementation of customer relationship management related to customization bonds influences customer loyalty.

Partially, financial bonds have been shown to have a substantial and beneficial impact on customer loyalty. This means that the greater the Customer Loyalty, the better the application of the Financial Bonds variable. The sample answers received will reflect the population; in other words, they can be standardized.

Customer Satisfaction is strongly affected by social ties. This means that the greater the consumer satisfaction, the better the application of the Social Bonds component. The survey answers received will represent the population; in other words, it can be generalized.

Partially states that Customization Bonds are proven to have a positive but have a negligible effect on customer loyalty. This means that the better the Customization Bonds variable's implementation, the higher the customer loyalty, but the sample answers obtained do not represent the population; in other words, it cannot be generalized.

\section{CONCLUSION}

Looking at the discussion results illustrated in the research implications in the previous chapter, 2 indicators are in the good enough category, namely the price-fixing needle in the Financial Bonds variable and the hand of the desire to use other business services on the Customer Loyalty variable. And overall, the financial bond variable is in a pretty good category. While other indicators both in the Social Bonds variable and the Customization Bonds variable are in a good variety, this indicator is considered good in its implementation by the customer and positively influences customer loyalty of PT. Amartha Sejahtera.
Referring to the results of this study, it is found that the number of theories stating that there is an effect of the implementation of Customer Relationship Management on Customer Loyalty is valid. In general, from this research, it is found that loyalty will always change, fierce competition and other companies' offers with various advantages make it easy for customers to move to other companies.

\section{REFERENCES}

[1] Bhaskara, S. U., Mandey, S. L., \& Nelwan, O. (2014). Customer Relationship Management (CRM) Dan Personal Selling Pengaruhnya Terhadap Kepuasan Konsumen Pada Pt Virgo Ekspres Tours \& Travel Manado. Jurnal EMBA: Jurnal Riset Ekonomi, Manajemen, Bisnis dan Akuntansi, 2(1).

[2] Bowen, J. T., \& Chen, S. L. (2001). The Relationship between Customer Loyalty and Customer Satisfaction. International Journal of Contemporary Hospitality Management.

[3] Chen, I. J., \& Popovich, K. (2003). Understanding Customer Relationship Management (CRM). Business Process Management Journal.

[4] Griffin, J. (1995). Customer loyalty. Esensi.

[5] Gummesson, E. (2011). Total Relationship Marketing. Routledge.

[6] Hoffman, N. P. (2000). An Examination of the" Sustainable Competitive Advantage" Concept: Past, Present, and Future. Academy of Marketing Science Review, 4(2000), 1-16.

[7] Kahaner, L. (1997). Competitive Intelligence: How To Gather Analyze and Use Information to Move Your Business to The Top. Simon and Schuster.

[8] Kasali, R. (1998). Membidik Pasar Indonesia: Segmentasi, Targeting, dan Positioning. Jakarta: Gramedia Pustaka Utama.

[9] Kotler, P., \& Keller, K. L. (2006). Marketing Management 12e. France: Edition Pearson Education.

[10] Parasuraman, A., \& Grewal, D. (2000). The Impact of Technology on the Quality-ValueLoyalty Chain: A Research Agenda. Journal of the Academy of Marketing Science, 28(1), 168-174.

[11] Rizal, M. (2003). Implementasi Strategi Customer Relationship Marketing untuk Meningkatkan Kepuasan dan Loyalitas Pelanggan. Skema, 1(3).

[12] Ryals, L. (2005). Making Customer Relationship Management Work: The Measurement and Profitable Management of 
Customer Relationships. Journal of Marketing, 69(4), 252-261.

[13] Rygielski, C., Wang, J. C., \& Yen, D. C. (2002). Data Mining Techniques for Customer Relationship Management. Technology in Society, 24(4), 483-502.

[14] Sugiyono. (2006). Metode Penelitian Bisnis. Bandung: CV. Alfabeta

[15] Wirtz, J., \& Lovelock, C. (2016). Services Marketing: People, Technology, Strategy. World Scientific Publishing Company.

[16] Yuan, S. T., \& Chang, W. L. (2001). MixedInitiative Synthesized Learning Approach for Web-Based CRM. Expert Systems with Applications, 20(2), 187-200.

[17] Zeithaml, V. A., Bitner, M. J., \& Gremler, D. D. (2018). Services Marketing: Integrating Customer Focus Aacross The Firm. McGrawHill Education, 